\title{
Plutarch
}

\section{On the daimonion of Socrates}

Human liberation, divine guidance and philosophy

Ed. by Heinz-Günther Nesselrath. Introduction, Text, Translation and Interpretative Essays by Donald A. Russell, George Cawkwell, Werner Deuse, John Dillon, HeinzGünther Nesselrath a.o.

[Über das daimonion des Socrates. Menschliche Befreiung, göttliche Führung und Philosophie.]

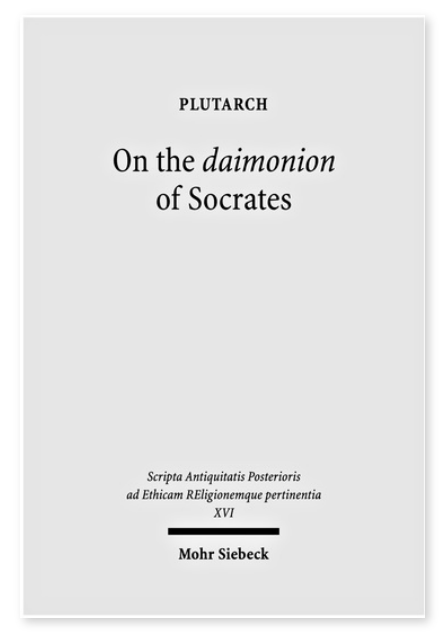

2010. X, 225 Seiten. SAPERE XVI

ISBN 978-3-16-156444-4 DOI 10.1628/978-3-16-156444-4 eBook PDF
Veröffentlicht auf Englisch.

Plutarchs Dialog 'Über das daimonion des Sokrates' ist eine einzigartige Verbindung einer spannenden historischen Erzählung mit einer ernsthaften philosophischen und religiösen Diskussion: Ein Erzähler aus dem böotischen Theben erzählt seinem athenischen Freund, wie Theben in einer schicksalhaften Nacht mitten im Winter 379/78 v.Chr. von spartanischer Herrschaft befreit wurde, und kombiniert dies mit der Wiedergabe eines faszinierenden philosophischen Gesprächs über das berühmte daimonion des Sokrates, das am vorangehenden Nachmittag und Abend stattfand. Neben einer Einleitung, einem revidierten griechischen Text und einer neuen englischen Übersetzung (mit ausführlichen Anmerkungen) bietet der Band eine Reihe von Essays, die weitere Einblicke in dieses meisterhafte Werk gewähren: zu seinem historischen, religiösen und philosophischen Hintergrund und zu thematischen Verbindungen mit weiteren Werken Plutarchs.

Plutarch Keine aktuellen Daten verfügbar.

Heinz-Günther Nesselrath Geboren 1957; 1976-81 Studium der Klassischen Philologie und der Alten Geschichte an der Universität zu Köln; 1981 Promotion; 1987 Habilitation; 1992-2001 vollamtlicher Professor für Klass. Philologie an der Universität Bern; seit 2001 Universitätsprofessor für Klass. Philologie an der Georg-August-Universität Göttingen.

George Cawkwell is Emeritus Fellow (Ancient History) of University College at the University of Oxford.

Werner Deuse is Professor of Ancient Languages at the University of Siegen.

John Dillon is Emeritus Professor of Greek at Trinity College Dublin.

Robert Parker is Wykeham Professor of Ancient History and Fellow of New College at the University of Oxford.

Christopher Pelling is Regius Professor of Greek at the University of Oxford.

Donald A. Russell Born 1920; professor of classical literature at the Faculty of Classics, University of Oxford; emeritus fellow and former tutor in classics at St John's College, Oxford.

Stephan Schröder is Professor of Classical Philology at the University of Erlangen.

Jetzt bestellen:

https://mohrsiebeck.com/buch/on-the-daimonion-of-socrates-9783161564444?no_cache=1

order@mohrsiebeck.com

Telefon: +49 (0)7071-923-17

Telefax: +49 (0)7071-51104 